GELANGGANG PENDIDIKAN JASMANI INDONESIA
Volume 1, Nomor 1, Tahun 2017

\title{
EVALUASI PELAKSANAAN KURIKULUM 2013 PADA MATAPELAJARAN PENDIDIKAN JASMANI OLAHRAGA DAN KESEHATAN DI SMPN 6 MALANG DENGAN MENGGUNAKAN ANALISIS SWOT
}

\author{
Suhardiyantoro Adhitya Wardhana \\ Asim \\ Heru Widijoto \\ Fakultas Ilmu Keolahragaan Universitas Negeri Malang \\ Email: aditdunks@gmail.com
}

\begin{abstract}
This study aimed to evaluate the implementation of the curriculum in 2013 on the subjects PJOK in SMPN 6 Malang. The study, using the type of evaluative research and using SWOT analysis. A research procedure that uses evaluative research based on SWOT, is strengths, weaknesses, opportunities and threats. The results of the evaluation of the implementation of the curriculum in 2013 by using SWOT analysis is at a very good standard of content. Excellent assessment standards. The standard process is very good. Competency standards either. Standard teachers and very good. Standard facilities and infrastructure are excellent. Standard finance is quite good and very good management standards.
\end{abstract}

Key words: curriculum evaluation in 2013 , sports physical education and health, SWOT analysis

\begin{abstract}
Abstrak: Penelitian ini bertujuan untuk mengevaluasi pelaksanaan kurikulum 2013 pada matapelajaran PJOK di SMPN 6 Malang. Penelitian yang menggunakan jenis penelitian evaluatif dan menggunakan analisis SWOT. Prosedur penelitian yaitu menggunakan penelitian evaluatif berdasarkan SWOT, yaitu kekuatan, kelemahan, peluang dan ancaman. Hasil evaluasi dari pelaksanaan kurikulum 2013 dengan menggunakan analisis SWOT adalah pada standar isi sangat baik. Standar penilaian sangat baik. Standar proses sangat baik. Standar kompetensi lulusan baik. Standar pendidik dan tenaga kependidikan sangat baik. Standar sarana dan prasarana sangat baik. Standar pembiayaan cukup baik dan standar pengelolaan sangat baik.
\end{abstract}

Kata Kunci: evaluasi kurikulum 2013, Pendidikan Jasmani Olahraga dan Kesehatan, analisis SWOT

Evaluasi terhadap kurikulum sangat penting karena berdampak langsung pada individu peserta didik di setiap jenjang pendidikan, peserta didik yang nantinya akan menjadi penerus bangsa. Sesuai dengan Permendikbud nomor 81A tahun 2013 tentang implementasi kurikulum "Evaluasi terhadap implementasi dilakukan untuk memberikan masukan terhadap proses pelaksanaan kurikulum agar sesuai dengan apa yang telah dirancang dalam dokumen. Evaluasi terhadap hasil memberikan keputusan me- ngenai dampak kurikulum terhadap individu warga negara, masyarakat, dan bangsa".

Evaluasi kurikulum harus sejalan dengan tujuan pendidikan nasional. Pernyataan ini diperkuat oleh Nasution (2010:60) "tujuan institusional adalah tujuan yang ingin dicapai oleh suatu lembaga pendidikan (SD, SM, Universitas), yang harus sesuai dengan tujuan pendidikan nasional. Tujuan institusional dapat dicapai melalui kurikulumnya, sehingga dapat dikatakan bahwa tujuan institusional sama dengan tujuan kurikuler dalam keseluruhan". 
Menurut Sukmadinata (2013:7) "kurikulum sebagai suatu sistem menyangkut penentuan segala kebijakan tentang kurikulum, prosedur pengembangan kurikulum, penerapan, evaluasi, dan penyempurnaannya".

Kurikulum 2013 merupakan salah satu program pemerintah Indonesia dalam bidang pendidikan, dengan implementasi program kurikulum 2013 ini diharapkan dapat membenahi permasalahan tujuan pendidikan Indonesia sebelumnya.

Mengacu pada Permendikbud no 68 tahun 2013, Secara umum Kurikulum 2013 bertujuan untuk mempersiapkan manusia Indonesia agar memiliki kemampuan hidup sebagai pribadi dan warga negara yang beriman, produktif, kreatif, inovatif, dan afektif serta mampu berkontribusi pada kehidupan bermasyarakat, berbangsa, bernegara, dan peradaban dunia. Selain itu tujuan kurikulum 2013 ini bertujuan untuk menyempurnakan pola pikir dan penguatan tata kelola kurikulum secara khusus.

Menurut Sunarti (2014:2) "melalui pendekatan tiga ranah itu, diharapkan siswa memiliki kompetensi sikap, pengetahuan, dan keterampilan yang jauh lebih baik. Mereka akan lebih kreatif, inovatif, dan lebih produktif, sehingga nantinya mereka akan sukses menghadapi persoalan dan tantangan".

Penyempurnaan pola pikir yang dimaksud adalah pola pembelajaran berpusat pada peserta didik, pola pembelajaran yang interaktif, pembelajaran secara jejaring, pembelajaran yang aktif mencari informasi dari segala sudut bidang, pembelajaran berbasis kelompok, pembelajaran berbasis multimedia, pembelajaran yang bersifat pelanggan dengan memperkaya potensi yang ada di peserta didik, pembelajaran yang bersifat jamak/multidisiplin dan pembelajaran yang kritis.

Untuk mencapai tujuan tersebut, maka lembaga harus mengukur dan menilai program tersebut dengan cara mengevaluasi kegiatan atau program tersebut. Menurut Tayibnapis (1989:6) "bila anda mengevaluasi suatu program, anda secara teratur mengumpulkan informasi tentang bagaimana program itu berjalan, tentang dampak yang mungkin terjadi atau untuk menjawab pertanyaan yang diminati. Kadang-kadang informasi yang dikumpulkan digunakan untuk membuat keputusan tentang program itu". Menurut Winarno (2004:4) "evaluasi merupakan suatu proses yang sistematis untuk menentukan nilai berdasarkan data yang dikumpulkan melalui pengukuran". Sedangkan Menurut Sukardi (2014:7) menyatakan bahwa "keberadaan evaluasi program juga penting ketika seorang penyelenggara lembaga kependidikan dan kepelatihan mengambil kebijakan untuk menilai program atau proyek dilaksanakan dengan efektif dan efisien".

Menurut Nasution (2010:3) "Evaluasi kurikulum adalah serangkaian tindakan sistematis dalam mengumpulkan informasi, pemberian pertimbangan dan keputusan mengenai nilai dan makna kurikulum. Pertimbangan dan keputusan mengenai nilai berkenaan dengan keajekan ide, desain, implementasi, dan hasil kurikulum", sesuai Permendikbud nomor 81A tahun 2013: Evaluasi terhadap implementasi dilakukan untuk memberikan masukan terhadap proses pelaksanaan kurikulum agar sesuai dengan apa yang telah dirancang dalam dokumen. Evaluasi terhadap hasil memberikan keputusan mengenai dampak kurikulum terhadap individu warga negara, masyarakat, dan bangsa. Secara singkat, evaluasi kurikulum dilakukan untuk menegakkan akuntabilitas kurikulum terhadap masyarakat dan bangsa.

Negara Indonesia saat ini menggunakan kurikulum 2013. Sesuai dengan Permendikbud nomor 68 tahun 2013: Kurikulum 2013 merupakan kurikulum yang dikembangkan atas teori pendidikan yang berdasarkan standar dan teori kurikulum berbasis kompetensi. Pendidikan berdasarkan standar menetapkan adanya standar nasional sebagai kualitas minimal warga negara yang dirinci menjadi standar isi, standar proses, standar kompetensi lulusan, standar pendidik dan tenaga kependidikan, standar sarana dan prasarana, standar pengelolaan, standar pembiayaan, dan standar penilaian.

Mengacu Permendikbud no 65 tahun 2013, Standar Proses adalah kriteria mengenai pelaksanaan pembelajaran pada satuan pendidikan untuk mencapai standar kompetensi lulusan. Proses pembelajaran pada satuan pendidikan diselenggarakan 
Suhardiyantoro A W, Evaluasi Pelaksanaan Kurikulum 2013 pada Matapelajaran Pendidikan Jasmani Olahraga dan Kesehatan di SMPN 6 Malang Dengan Menggunakan Analisis SWOT

secara interaktif, inspiratif, menyenangkan, menantang, memotivasi peserta didik untuk berpartisipasi aktif, serta memberikan ruang yang cukup bagi prakarsa, kreativitas, dan kemandirian sesuai dengan bakat, minat, dan perkembangan fisik serta psikologis peserta didik.

Mengacu Permendikbud no 66 tahun 2013, Standar penilaian pendidikan adalah kriteria mengenai mekanisme, prosedur, dan instrumen penilaian hasil belajar peserta didik. Penilaian pendidikan sebagai proses pengumpulan dan pengolahan informasi untuk mengukur pencapaian hasil belajar peserta didik mencakup: penilaian otentik, penilaian diri, penilaian berbasis portofolio, ulangan, ulangan harian, ulangan tengah semester, ulangan akhir semester, ujian tingkat kompetensi, ujian mutu tingkat kompetensi, ujian nasional, dan ujian sekolah/madrasah.

Menurut Sunarti (2014:9) mengatakan tentang penilaian sebagai berikut. Penilaian mencakup semua proses pembelajaran. Oleh karena itu, kegiatan penilaian tidak terbatas pada karakteristik peserta didik saja, tetapi juga mencakup karakteristik metode mengajar, kurikulum, fasilitas, dan administrasi sekolah. Instrumen penilaian untuk peserta didik dapat berupa metode atau prosedur formal atau informal untuk menghasilkan informasi tentang peserta didik. Instrumen penilaian dapat berupa tes tertulis, tes lisan, lembar pengamatan, pedoman wawancara, tugas rumah, dan sebagainya. Evaluasi memerlukan data hasil pengukuran dan informasi hasil penilaian yang memiliki banyak dimensi, seperti kemamuan kreatifitas, sikap, minat, keterampilan, dan sebagainya.

Menurut Sudjana (1990:57) Komponen pengajaran sebagai dimensi penilaian proses belajar mengajar mencakup: “a) Tujuan pengajaran atau tujuan instruksional, b) Bahan pengajaran, c) Kondisi siswa dan kegiatan belajarnya, d) Kondisi guru dan kegiatan mengajarnya, e) Alat dan sumber belajar yang digunakan, dan f) Teknik dan cara pelaksanaan penilaian".

Mengacu Permendikbud no 64 tahun 2013, Upaya mewujudkan tujuan pendidikan nasional tersebut telah ditetapkan standar kompetensi lulusan yang merupakan kriteria mengenai kualifikasi kemampuan lulusan yang mencakup sikap, pengetahuan, dan keterampilan. Untuk mencapai kompetensi lulusan tersebut perlu ditetapkan standar isi yang merupakan kriteria mengenai ruang lingkup materi dan tingkat kompetensi peserta didik untuk mencapai kompetensi lulusan pada jenjang dan jenis pendidikan tertentu.

Mengacu Permendikbud no 54 tahun 2013, Standar Kompetensi Lulusan adalah kriteria mengenai kualifikasi kemampuan lulusan yang mencakup sikap, pengetahuan, dan keterampilan. Tujuan dari standar kompetensi lulusan digunakan sebagai acuan utama pengembangan standar isi, standar proses, standar penilaian pendidikan, standar pendidik dan tenaga kependidikan, standar sarana dan prasarana, standar pengelolaan, dan standar pembiayaan.

Mengacu Permendiknas no 24 tahun 2007, pelaksanaan pembelajaran dalam pendidikan nasional berpusat pada peserta didik agar dapat: belajar untuk beriman dan bertakwa kepada Tuhan Yang Maha Esa, belajar untuk memahami dan menghayati, belajar untuk mampu melaksanakan dan berbuat secara efektif, belajar untuk hidup bersama dan berguna bagi orang lain, dan belajar untuk membangun dan menemukan jati diri melalui proses belajar yang aktif, kreatif, efektif, dan menyenangkan. Untuk menjamin terwujudnya hal tersebut diperlukan adanya sarana dan prasarana yang memadai. Sarana dan prasarana yang memadai tersebut harus memenuhi ketentuan minimum yang ditetapkan dalam standar sarana dan prasarana.

Menurut Yusuf (2012:3) "kondisi sarana dan prasarana olahraga mempengaruhi proses belajar mengajar baik terhadap kurikulum, guru, dan peserta didik. Semakin baik kondisi sarana dan prasarana olahraga, maka semakin baik pula pengaruh terhadap kurikulum, guru dan peserta didik dan begitu pula sebaliknya". Sarana olahraga dibedakan menjadi peralatan dan perlengkapan dan prasarana merupakan sesuatu yang sulit untuk dipindahkan.

Sarana olahraga meliputi bola basket, bola voli, bola sepak, jaring, gawang, ring basket, net voli, patcing pad, body protector, raket, bendera, palang, lembing, balok start, tongkat estafet, matras, peti lompat, tali lompat, tiang, mistar untuk lompat tinggi. Prasarana olahraga meliputi lapangan 
atletik, lapangan sepak bola, lapangan basket, lapangan voli, lapangan kasti ruang senam dan lapangan serba guna.

Mengacu Permendiknas no 69 tahun 2009, Standar biaya operasi nonpersonalia untuk SD/MI, SMP/MTs, SMA/MA, SMK, SDLB, SMPLB, dan SMALB adalah standar biaya yang diperlukan untuk membiayai kegiatan operasi nonpersonalia selama 1 (satu) tahun untuk SD/MI, SMP/MTs, SMA/MA, SMK, SDLB, SMPLB, dan SMALB sebagai bagian dari keseluruhan dana pendidikan agar satuan pendidikan dapat melakukan kegiatan pendidikan secara teratur dan berkelanjutan sesuai Standar Nasional Pendidikan.

Mengacu Permendiknas no 32 tahun 2008, Sistem pendidikan nasional dimaksudkan untuk menjamin pemerataan kesempatan pendidikan, peningkatan mutu, relevansi, dan efisiensi manajemen pendidikan untuk menghadapi tuntutan perubahan kehidupan lokal, nasional dan global. Dalam rangka peningkatan mutu pendidikan, ditetapkan Peraturan Pemerintah Republik Indonesia Nomor 19 Tahun 2005 tentang Standar Nasional Pendidikan, di antaranya mengatur tentang standar pendidik yang harus menjadi acuan sekaligus kriteria dalam menetapkan keberhasilan penyelenggaraan pendidikan.

Menurut Mulyasa (2007:26) "kompetensi guru merupakan perpaduan antara kemampuan personal, keilmuan, teknologi, sosial dan spritual yang secara kaffah membentuk kompetensi standar profesi guru, yang mencakup penguasaan materi, pemahaman terhadap peserta didik, pembelajaran yang dapat mendidik peserta didik, pengembangan pribadi mereka dan profesionalisme".

Mengacu Permendiknas no 19 tahun 2007, Standar pengelolaan mencakup: Setiap guru bertanggungjawab menyusun silabus setiap mata pelajaran yang diampunya sesuai dengan Standar Isi, Standar Kompetensi Lulusan. Dalam penyusunan silabus ini, guru matapelajaran dapat bekerjasama dengan Kelompok Kerja Guru (KKG), Musyawarah Guru Mata Pelajaran (MGMP), Lembaga Penjamin Mutu Pendidikan (LPMP), atau Perguruan Tinggi.

Implementasi kurikulum 2013 mengalami banyak hambatan, menurut Febri
Hendri CO Monitoring Kebijakan Publik ICW, "banyak guru mengeluh tidak memahami materi kurikulum 2013. Alhasil, sebagian sekolah tetap menggunakan kurikulum 2006 yang lebih dipahami oleh guru" (Suara Pembaruan. 2014) dan menurut Paat seorang pengamat pendidikan dari Universitas Negeri Jakarta mengatakan "implementasi kurikulum 2013 terlalu dipaksakan, selain itu perubahan dari kurikulum lama menjadi kurikulum 2013 tidak berdasarkan kajian akademik. Karena sampai saat ini naskah akademiknya tidak ada" (Suara Pembaruan. 2014). Oleh karena melihat berbagai kendala dalam implementasi kurikulum 2013, Anies Baswedan selaku Menteri Pendidikan dan Kebudayaan mendesak untuk diadakannya evaluasi terhadap implementasi kurikulum 2013.

Berdasarkan hasil evaluasi tersebut, maka Mendikbud memutuskan untuk memberlakukan kurikulum 2013 secara terbatas (Permendikbud 160/2014). Berdasarkan aturan ini, hanya sekolah yang boleh menerapkan kurikulum ini adalah sekolah yang telah menerapkan kurikulum selama 3 semester. Sekolah yang belum menerapkan selama 3 semester, kembali menerapkan kurikulum 2006. Pemerintah akan berusaha membenahi kendala ini sehingga pada tahun ajaran 2019/2020 semua sekolah di Indonesia akan menerapkan kurikulum 2013 ini secara menyeluruh.

Untuk mewujudkan penerapan kurikulum 2013 secara menyeluruh, pemerintah membuat program-program yang sesuai dengan hal itu. Pelatihan guru merupakan salah satu program yang dicanangkan pemerintah dalam kurun waktu 2-3 tahun ke depan. Program ini oleh Mendikbud merupakan prioritas, karena beliau berkata akan melatih guru sampai siap untuk menerapkan kurikulum 2013. Selain menyiapkan guru, pemerintah akan mengadakan evaluasi terhadap implementasi kurikulum 2013 secara bertahap di sekolah-sekolah yang kembali menerapkan kurikulum 2006.

Alasan utama peneliti yaitu akan mengevaluasi pelaksanaan kurikulum, pada standar isi, proses, penilaian, kompetensi lulusan, pendidik dan tenaga kependidikan, sarana-prasarana, pengelolaan dan pembiayaan yang ada di sekolah SMPN 6 Malang pada matapelajaran Pendidikan 
Suhardiyantoro A W, Evaluasi Pelaksanaan Kurikulum 2013 pada Matapelajaran Pendidikan Jasmani Olahraga dan Kesehatan di SMPN 6 Malang Dengan Menggunakan Analisis SWOT

Jasmani, Olahraga dan kesehatan dengan menggunakan analisis SWOT. Dengan adanya evaluasi kurikulum ini diharapkan sekolah dapat mengethui sejauh mana SMPN 6 Malang telah menjalankan kurikulum 2013 ini, dan sekolah dapat membenahi permasalahan dengan rekomendasi peneliti. Berdasarkan latar belakang masalah serta beberapa landasan teori yang telah dipaparkan oleh peneliti, peneliti telah melakukan penelitian yang berjudul "Evaluasi Pelaksanaan Kurikulum 2013 pada Matapelajaran Pendidikan Jasmani Olahraga dan Kesehatan di SMPN 6 Malang Dengan Menggunakan Analisis SWOT".

\section{METODE}

Model penelitian yang digunakan adalah penelitian evaluasi menurut Nasution (2010:90) menguraikan tentang data yang harus dikumpulkan dan analisa data untuk membuktikan nilai dan efektivitas kurikulum.

Desain evaluasi ada lima langkah, yakni: 1) Merumuskan tujuan evaluasi. 2) Mendesain proses dan metodologi evaluasi. 3) Menspesifikkan data yang diperlukan untuk menyusun instrumen bagi proses pengumpulan data. 4) Mengumpulkan, menyusun dan mengolah data. 5) Menganalisis data dan menyusun laporan mengenai hasil-hasil, kesimpulan dan rekomendasi.

Subyek penelitian dalam penelitian ini adalah Guru Pendidikan Jasmani, Olahraga, dan Kesehatan SMPN 6 Malang dan Wakil Kepala Urusan Sarana-Prasarana. Instrumen pengumpulan data menggunakan kuesioner dengan skala likert yaitu 4 alternatif jawaban yang dapat dipilih. Keempat pilihan jawaban tersebut adalah selalu, sering, jarang dan tidak pernah. Jika memilih jawaban selalu, akan mendapat skor 4 . Jika memilih jawaban sering, akan mendapatkan skor 3. Jika memilih jawaban jarang, akan mendapat nilai 2. Jika memilih jawaban tidak pernah, akan mendapat nilai 1 . Pengambilan data di ambil peneliti pada bulan september 2016 sampai oktober 2016.

Penelitian ini memiliki 2 jenis data, yaitu data kualitatif berupa informasi non angka yang dikumpulkan dari instrumen penelitian dan data kuantitatif berupa informasi tentang angka atau nominal yang di dapat berdasarkan instrumen penelitian.
Penelitian ini memiliki 2 jenis sumber data, yaitu data primer adalah data yang diperoleh langsung berdasarkan instrumen penelitian. data sekunder adalah data yang diperoleh berdasarkan sumber data kedua, dapat berupa tulisan atau lisan.

Analisis data dilakukan dengan cara 3 analisis data, yaitu: 1) Deskriptif Kualitatif yang mendeskripsikan hasil penelitian berupa narasi hasil penelitian (Sugiyono, 2011), 2) Deskripsif Kuantitatif yang menjelaskan data berupa angka-angka hasil penelitian (Sugiyono, 2011), dan 3) analisis SWOT yang menjelaskan kekuatan, kelemahan, peluang dan ancaman dari program Kurikulum 2013 (Rangkuti, 2003).

Analisis SWOT ini merupakan analisis yang pada umumnya digunakan dalam dunia bisnis. Analisis ini tentang bagaimana cara pemasaran, cara mengatasi kendala-kendala yang ada di suatu perusahaan maupun cara menganalisa pasar dunia bisnis.

Analisis ini juga bisa melihat sejauh mana perusahaan tersebut berkembang dalam hal visi, tujuan perusahaan maupun kebijakan yang diambil oleh perusahaan itu sendiri. Pernyataan di atas sesuai dengan Rangkuti (2003:19) mengenai "analisis SWOT adalah analisis ini didasarkan pada logika yang dapat memaksimalkan kekuatan dan peluang, namun secara bersamaan dapat meminimalkan kelemahan dan ancaman. Proses pengambilan keputusan strategis selalu berkaitan dengan pengembangan misi, tujuan, strategi dan kebijakan perusahaan".

Menurut Pearce dan Robinson (2009: 200). Analisis SWOT merupakan teknik historis yang terkenal dimana para manajer menciptakan gambaran umum secara cepat mengenai situasi strategis perusahaan. Anaisis ini didasarkan pada asumsi bahwa strategi yang efektif diturunkan dari kesesuaian yang baik antara sumber daya internal perusahaan (kekuatan-kelemahan) dengan situasi eksternal (peluang-ancaman). Dalam analisis matrix SWOT diterapkan sistem "skoring" untuk unsurunsur yang dianggap penting. Makna pemberian persen-tase skor dapat terlihat pada tabel berikut.

Tabel 1. Persentase Skor

\begin{tabular}{lc}
\hline Skor SWOT \% & Makna \\
\hline $90-100$ & Tertinggi dalam SWOT \\
\hline
\end{tabular}




\begin{tabular}{ll}
\hline Skor SWOT \% & \multicolumn{1}{c}{ Makna } \\
\hline $80-89$ & Sangat Tinggi atau jelas SWOT \\
$70-79$ & Tinggi SWOT \\
$60-69$ & Unsur penting SWOT \\
$50-59$ & Parsial SWOT \\
$40-49$ & Salah satu/dua wilayah SWOT \\
$30-39$ & Kecil sekali SWOT \\
$20-29$ & Hampir tidak ada SWOT \\
$0-19$ & Tidak ada SWOT \\
\hline
\end{tabular}

(Sumber: Sawitri, 2014)

\section{HASIL}

Berdasarkan penelitian yang dilakukan melalui proses pengambilan data peneliti tentang implementasi kurikulum 2013 di SMPN 6 Malang, maka diperoleh gambaran tentang implementasi kurikulum 2013 di SMPN 6 Malang. Berikut ini merupakan pemaparan hasil penelitian dengan menggunakan deskriptif kualitatif, deskriptif kuantitatif dan analisis SWOT:

\section{Standar Isi}

\section{Tabel 2. Analisis SWOT Standar Isi}

\begin{tabular}{lll}
\hline Strenght & $\bullet$ & Materi dapat disederhanakan oleh guru. \\
& $\bullet$ & Guru memberi tes awal kepada peserta didik/ apersepsi. \\
& $\bullet$ & Penilaian guru berupa penilaian otentik: proses dan produk. \\
\hline Weakness & $\bullet$ & Tidak bisa mengukur pemahaman peserta didik dengan cara yang sama. \\
& $\bullet$ & Tidak semua materi yang diajarkan guru dapat dimengerti peserta didik. \\
\hline Opportunity & $\bullet$ & Guru dapat memberi materi pengayaan. \\
\hline Threatening & $\bullet$ & Untuk peserta didik yang tidak masuk atau tidak mengerti materi yang diajarkan maka \\
& & peserta didik tersebut akan semakin tertinggal peserta didik lain. \\
\hline
\end{tabular}

Berdasarkan paparan di atas diketahui bahwa standar isi kurikulum 2013 sudah berjalan baik. Hal ini ditinjau dari cara guru memperlakukan peserta didik dengan baik. Untuk mengatasi ancaman yang ada, sebaiknya guru membuat grup peserta didik yang berisi setengahnya peserta didik yang menguasai materi secara penuh dan setengahnya adalah peserta didik yang menguasai materi secara pas-pasan.

\section{Standar Penilaian}

Berdasarkan hasil penelitian, guru menggunakan penilaian otentik dan membuat kriteria penilaian otentik dalam pembelajaran. Guru menggunakan penilaian diri dalam setiap pembelajaran. Guru jarang memberikan tugas portofolio kepada peserta didik. Guru selalu mengadakan ulangan
Berdasarkan hasil penelitian pada subvariabel karakteristik materi, guru menjelaskan bahwa cara guru untuk menyesuaikan karakteristik materi agar sesuai dengan karakter peserta didik adalah materi disederhanakan tingkat kesulitannya sesuai dengan kemampuan peserta didiknya.

Subvariabel kesesuaian materi, guru menjelaskan bahwa cara untuk menyesuaikan materi untuk peserta didik adalah memberi tes awal pada peserta didik materi yang akan diajarkan. Subvariabel kecukupan materi, guru menjelaskan cara untuk mengukur kecukupan materi adalah dengan cara melakukan penilaian otentik, yaitu: penilaian proses dan penilaian produk.

Subvariabel keluasan materi, guru menjelaskan bahwa cara untuk mengukur keluasan materi adalah melakukan analisis esensial pada komptensi dasar kurikulum 2013. Subvariabel kedalaman materi, guru menjelaskan cara untuk mengukur kedalaman materi adalah dengan cara memberi materi pengayaan pada peserta didik. harian, mengoreksi dan mengembalikan hasil ulangan harian kepada peserta didik.

Guru mengadakan ulangan tengah semester, mengoreksi dan mengembalikan hasil ulangan tengah semester kepada peserta didik. Guru mengadakan ulangan akhir semester, mengoreksi dan selalu mengembalikan hasil ulangan akhir semester kepada peserta didik. Guru juga mengadakan remidi apabila nilai dari ulanganulangan tersebut belum mencapai kriteria kelulusan.

Guru menggunakan penilaian sikap, yaitu penilaian diri dan penilaian teman sejawat, dan guru membuat kriteria untuk penilaian diri dan penilaian teman sejawat tersebut. Guru mengadakan tes tulis dan membuat kriteria tes tulis tersebut. Guru jarang menggunakan tes lisan terhadap 
Suhardiyantoro A W, Evaluasi Pelaksanaan Kurikulum 2013 pada Matapelajaran Pendidikan Jasmani Olahraga dan Kesehatan di SMPN 6 Malang Dengan Menggunakan Analisis SWOT

peserta didik. Guru membuat lembar observasi untuk menilai peserta didik dan membuat kriterianya.

\section{Tabel 3. Analisis SWOT Standar Penilaian}

\begin{tabular}{|c|c|}
\hline Strenght & $\begin{array}{l}\text { - Guru menggunakan penilaian otentik dan membuat kriteria penilaian tersebut. } \\
\text { - Guru menggunakan penilaian diri di setiap pembelajaran. } \\
\text { - Guru selalu mengoreksi pekerjaan pseserta didik. } \\
\text { - } \text { Guru selalu mengadakan ulangan harian, mengoreksi ulangan tersebut dan } \\
\text { - Guru selalu mengadakan ulangan tengah semester, mengoreksi ulangan tersebut } \\
\text { - } \text { dan membeberkan kepada peserta didik. } \\
\text { - } \text { kelulusan. } \\
\text { - Guru selalu mengadakan ulangan akhir semester, mengoreksi ulangan tersebut dan } \\
\text { - Guru menggunakan penilaian kompetensi sikap. } \\
\text { - Guru melakukan observasi untuk penilaian peserta didik. } \\
\text { - Guru selalu mengisi jurnal mengajar. } \\
\text { - Guru membuat skala penilaian tes tulis. }\end{array}$ \\
\hline Weakness & $\begin{array}{l}\text { - Guru jarang mengadakan tes lisan kepada peserta didik. } \\
\text { - Guru jarang memberi tugas portofolio. }\end{array}$ \\
\hline Opportunity & - Guru sering memberi tugas penguatan kepada peserta didik. \\
\hline Threatening & - Penilaian diri dan penilaian teman sejawat sering disalahgunakan peserta didik \\
\hline
\end{tabular}

Berdasarkan uraian di atas dapat diketahui bahwa standar penilaian sudah berjalan baik. Untuk mengatasi ancaman yang ada, guru selalu memegang penilaian observasinya dan menghimbau pada peserta didiknya agar mengukur kemampuannya sendiri dalam menialai dirinya, agar mereka bisa objektif terhadap penilaian diri dan penilaian teman sejawat.

\section{Standar Proses}

Berdasarkan hasil penelitian, guru selalu membuat program tahunan, program semester dan RPP berdasarkan kurikulum 2013. Guru juga membuat silabus yang mengacu pada kurikulum 2013. Guru memasukkan pembelajaran konseptual pada peserta didik. Guru mengondisikan peserta didik sebelum pembelajaran dimulai. Guru selalu meng- gunakan volume dan intonasi suara yang jelas.

Guru juga menciptakan situasi pembelajaran yang kondusif dan aman. Guru selalu memberikan apersepsi, motivasi dan menjelaskan tujuan pembelajaran sebelum memulai pembelajaran. Guru menggunakan model dan metode yang sesuai dengan peserta didik. Guru melakukan refleksi dan memberikan umpan balik di akhir pembelajaran.

Pada kuesioner yang di isi oleh guru PJOK, pada jawaban selalu mendapatkan skor 80 dari 96 total skor yang ada, dan mendapatkan persentase sejumlah $83,3 \%$. Jawaban sering mendapat skor 6 dan mendapatkan persentase sejumlah $6,2 \%$, pada jawaban jarang mendapat skor 2 dan mendapat persentase sejumlah $2 \%$ dan persentase $1 \%$ untuk jawaban tidak pernah.

\section{Tabel 4. Analisis SWOT Standar Proses}

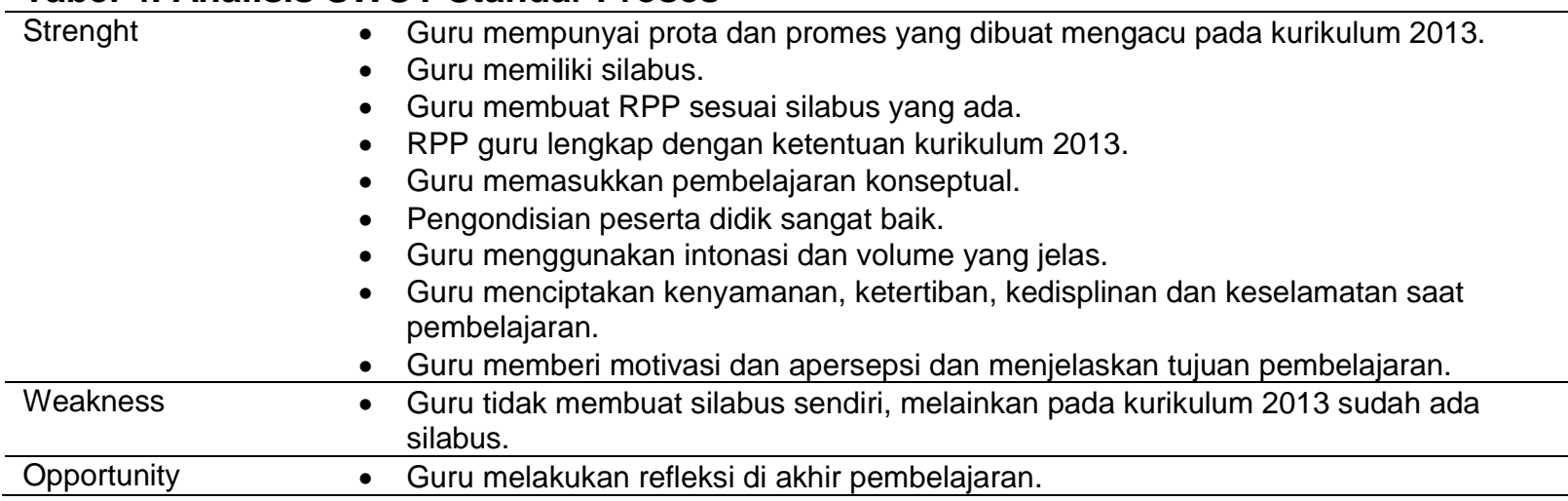




\begin{tabular}{lll}
\hline & $\bullet$ & Guru memberi umpan balik kepada peserta didik. \\
\hline Threatening & $\bullet$ & Guru tidak menyesuaiakan model dan metode untuk peserta didik. \\
\hline
\end{tabular}

Dari uraian di atas dapat diketahui bahwa standar proses ini berjalan sangat baik. Hal ini disebabkan bahwa guru memiliki perangakat pembelajaran yang lengkap dan selalu melakukan refleksi dan feedback kepada peserta didik.

\section{Standar Kompetensi Lulusan}

Berdasarkan hasil penelitian, guru mempunyai standar kompetensi lulusan kurikulum 2013. Guru mengembangkan standar isi mengacu pada standar kompetensi lulusan. Guru mengembangkan standar proses mengacu pada standar kompetensi lulusan. Guru mengembangkan standar penilaian mengacu pada standar kompetensi lulusan. Guru membentuk peserta didik agar beriman, berilmu, percaya diri dan bertanggung jawab. Guru membentuk peserta didik agar memiliki pengetahuan faktual, konseptual dan prosedural.

Pada kuesioner yang di isi oleh guru PJOK, pada jawaban selalu mendapatkan skor 24 dari 32 total skor yang ada, dan mendapatkan persentase sejumlah $75 \%$. Jawaban sering mendapat skor 6 dan mendapatkan persentase sejumlah 18,7\%, pada jawaban jarang mendapat mendapat persentase $0 \%$ dan persentase $1 \%$ untuk jawaban tidak pernah.

\section{Tabel 5. Analisis SWOT Standar Kompetensi Lulusan}

\begin{tabular}{lll}
\hline Strenght & $\bullet$ & Guru mempunyai SKL kurikulum 2013 \\
& $\bullet$ & Guru mengembangkan standar isi, proses dan penilaian mengacu pada SKL. \\
& & Guru membentuk peserta didik agar beriman, berilmu, percaya diri dan bertanggung \\
& - & Guru membentuk peserta didik agar memiliki pengetahuan faktual, konseptual dan \\
& prosedural. \\
& - & Guru membentuk peserta didik agar memiliki kemampuan berfikir efektif dan efisien. \\
\hline Weakness & - & Membentuk peserta didik memerlukan waktu yang lama. \\
\hline Opportunity & $\bullet$ & Peserta didik dapat mencapai SKL setelah lulus. \\
\hline Threatening & $\bullet$ & Pengaruh eksternal peserta didik. \\
\hline
\end{tabular}

Berdasarkan uraian di atas diketahui bahwa pelaksanaan standar kompetensi lulusan kurikulum 2013 beserta implementtasinya sudah berjalan baik. Untuk mengatasi kelemahan dan ancaman yang ada pada standar ini, maka guru harus membuat pembelajaran yang menyenangkan agar materi yang diajarkan dapat dipahami oleh peserta didik dan memberi perhatian kepada peserta didik yang memiliki masalah eksternal sekolah.

\section{Standar Pendidik dan Tenaga Kependi- dikan}

Berdasarkan hasil penelitian, 4 kompetensi guru disajikan sebagai berikut. Subvariabel kompetensi pedagogik, guru dapat mengenal karakter peserta didik. Guru dapat memahami dan mengembangkan potensi peserta didik. Guru dapat menguasai teori model-model pembelajaran. Guru dapat menguasai metode-metode pembelajaran. Guru dapat mengembangkan materi secara kreatif dan menyenangkan. Guru dapat berkomunikasi dengan efektif dan efisien. Guru dapat menilai peserta didik secara objektif dan mengevaluasi kesalahan peserta didik.

Subvariabel kepribadian, guru dapat dijadikan panutan peserta didik. Guru bijaksana dalam mengambil keputusan dan dapat berbuat adil kepada siapapun. Guru harus berwibawa dan dapat instrospeksi diri. guru harus bisa mengevaluasi kinerjanya sendiri. Guru harus pantang menyerah.

Subvariabel profesional, guru harus dinamis dan mengikuti perkembangan ilmu pengetahuan pendidikan jasmani. Guru harus menguasai materi secara luas dan menyeluruh. Guru dapat menerapkan ilmu yang di dapat dalam pembelajaran. Guru pendidikan jasmani harus menerapkan teori yang sesuai dengan pendidikan jasmani.

Subvariabel sosial, guru dapat bergaul dengan semua warga sekolah. Guru harus bertindak sesuai norma yang berlaku. Guru 
Suhardiyantoro A W, Evaluasi Pelaksanaan Kurikulum 2013 pada Matapelajaran Pendidikan Jasmani Olahraga dan Kesehatan di SMPN 6 Malang Dengan Menggunakan Analisis SWOT

harus dapat bekerja sama dengan baik dengan siapapun. Guru harus dapat berkomunikasi dengan baik.

Pada kuesioner yang di isi oleh guru PJOK, pada jawaban selalu mendapatkan skor 40 dari 96 total skor yang ada, dan mendapatkan persentase sejumlah $41,7 \%$.
Jawaban sering mendapat skor 42 dan mendapatkan persentase sejumlah 43,7\%, pada jawaban jarang mendapat mendapat persentase $0 \%$ dan persentase $0 \%$ untuk jawaban tidak pernah.

\section{Tabel 6. Analisis SWOT Standar Pendidik dan Tenaga Kependidikan}

\begin{tabular}{|c|c|}
\hline Strenght & $\begin{array}{l}\text { - } \text { Guru dapat berkomunikasi dengan efektif dan efisien. } \\
\text { - } \quad \text { Guru dapat menilai obyektif kepada peserta didik. } \\
\text { - Guru dapat mengevaluasi kesalahan peserta didik. } \\
\text { - Guru merupakan panutan yang harus di contoh peserta didik. } \\
\text { - Guru dapat bertindak adil terhadap warga sekolah. } \\
\text { - Guru harus berwibawa, pantang menyerah,dinamis dan mudah bergaul. }\end{array}$ \\
\hline Weakness & - Guru tidak bisa mengevaluasi kinerjanya sendiri. \\
\hline Opportunity & $\begin{array}{l}\text { - } \quad \text { Guru harus berupaya untuk mengenal karakteristik pesrta didik. } \\
\text { - } \quad \text { Guru harus berupaya untuk meningkatkan potensi peserta didik. } \\
\text { - } \quad \text { Guru harus lebih memahami model-model pembelajran. } \\
\text { - }\end{array}$ \\
\hline Threatening & - Manajemen waktu guru. \\
\hline
\end{tabular}

Pada kuesioner yang di isi oleh Waka Sarana dan Prasarana, pada jawaban selalu mendapatkan skor 84 dari 108 total skor yang ada, dan mendapatkan persentase sejumlah $77,8 \%$. Jawaban sering mendapat skor 6 dan mendapatkan persentase sejumlah 5,5\%, pada jawaban jarang mendapat mendapat persentase $1,8 \%$ dan persentase $2,7 \%$ untuk jawaban tidak pernah.

\section{Tabel 7. Analisis SWOT Standar Sarana dan Prasarana}

\begin{tabular}{|c|c|}
\hline Strenght & $\begin{array}{l}\text { - } \quad \text { Lingkungan sekolah bebas bahaya. } \\
\text { - } \quad \text { Sangunan sekolah tidak ada yang rapuh. } \\
\text { - } \quad \text { Tanolah bebas dari kecelakaan lalu lintas. } \\
\text { - } \quad \text { Tempat sampah di sekolah mencukupi untuk volume sampah } 1 \text { hari. } \\
\text { - Sekolah terhindar dari pencemaran air dan pencemaran udara } \\
\text { - Setiap ruangan di sekolah memiliki sistem sirkulasi udara dan penerangan yang } \\
\text { - } \quad \text { Saik. } \\
\text { - } \quad \text { Meja dan kursi cukup untuk oeserta didik dan guru. } \\
\text { - } \quad \text { Tempat berolah tempat berolahraga memiliki pohon yang banyak. } \\
\text { - } \quad \text { Guru memiliki ruangan khusus untuk menyimpan sarana dan prasarana olahraga. }\end{array}$ \\
\hline Weakness & $\begin{array}{l}\text { - } \quad \text { Alat pemadam kebakaran di sekolah sangat sedikit. } \\
\text { - } \quad \text { Samar mandi sekolah harus bersih. } \\
\text { - Sekolah tidak terhindar dari kebisingan kendaraan bermotor karena letaknya sangat } \\
\text { - Sekat dengan jalan raya. } \\
\text { - } \quad \text { Lokasi sekolah yang dekat dengan jalan raya berakibat pada polusi udara. } \\
\text { - Tempat berolahraga digunakan sebagai parkir kendaraan. }\end{array}$ \\
\hline Opportunity & - Sekolah mempunyai akses keselamatan bila terjadi bencana alam. \\
\hline Threatening & $\begin{array}{l}\text { - Sekolah rawan terjadi kebakaran karena alat pemadamnya sedikit. } \\
\text { - } \quad \text { Pembelajaran bisa terganggu akibat kebisingan. } \\
\text { - } \quad \text { Udara di sekolah kurang baik. } \\
\text { - Lahan berolahraga dipersempit dengan digunakan sebagai lahan parkir. }\end{array}$ \\
\hline
\end{tabular}

Dari uraian di atas diketahui bahwa standar sarana-prasarana ini cukup baik dan perlu sedikit pembenahan pada penyediaan alat pemadam kebakaran dan lahan parkir 
sehingga tidak mengganggu aktivitas olahraga peserta didik.

\section{Standar Pembiayaan}

Berdasarkan hasil penelitian, Sekolah menyediakan plot dana apabila ada kejadian kecelakaan di luar kesengajaan manusia yang terjadi di sekolah. Baik tertimpa oleh peserta didik maupun guru dan warga sekolah lainnya. Biaya asuransi keselamatan dan kesehatan harus dibuat di masingmasing sekolah. Meskipun beberapa guru memiliki jaminan kesehatan sendiri, sekolah juga menyiapkan biaya cadangan apabila hal-hal yang tidak diinginkan terjadi. Guru juga harus membuat proposal perbaikan sarana-prasarana olahraga bila terjadi kerusakan pada sarana-prasarana olahraga. Pada kuesioner yang di isi oleh guru PJOK, pada jawaban selalu mendapatkan skor 12 dari 28 total skor yang ada, dan mendapatkan persentase sejumlah $42,8 \%$. Jawaban sering mendapat skor 0 dan mendapatkan persentase sejumlah $0 \%$, pada jawaban jarang mendapat mendapat persentase $7,1 \%$ dan persentase $10,7 \%$ untuk jawaban tidak pernah

\section{Tabel 8. Analisis SWOT Standar Pembiayaan}

\begin{tabular}{|c|c|}
\hline Strenght & $\begin{array}{l}\text { - Sekolah mempunyai plot dana khusus untuk matapelajaran Pendidikan Jasmani } \\
\text { Olahraga dan Kesehatan. } \\
\text { - } \quad \text { Ada dana khusus untuk perbaikan prasarana olahraga. } \\
\text { - Sika terjadi kecelakaan maka semua biaya di tanggung pihak sekolah. } \\
\text { - Sekolah bertanggung jawab atas semua kerusakan fasilitas olahraga yang } \\
\text { diakibatkan oleh peserta didik. }\end{array}$ \\
\hline Weakness & - Guru tidak mengajukan proposal pengadaan alat tiap semester. \\
\hline Opportunity & $\begin{array}{l}\text { - Pihak sekolah tidak menyediakan dana untuk kegiatan luar sekolah seperti kegiatan } \\
\text { outbound dll. }\end{array}$ \\
\hline Threatening & $\begin{array}{l}\text { - } \quad \text { Tidak ada biaya asuransi jika terjadi kecelakaan pada peserta didik saat } \\
\text { pembelajaran. } \\
\text { - } \quad \text { Tidak ada biaya asuransi jika terjadi kecelakaan pada guru saat pembelajaran. }\end{array}$ \\
\hline
\end{tabular}

Berdasarkan uraian di atas dapat diketahui bahwa kegiatan pembiayaan di sekolah ini cukup untuk memelihara fasilitas yang ada. Tetapi sekolah tidak mengadakan biaya untuk keperluan olahraga luar sekolah seperti renang atau outbound.

\section{Standar Pengelolaan}

Berdasarkan hasil penelitian, guru mengembangkan kurikulum 2013 sesuai dengan karakter, sosial budaya warga sekitar. Guru aktif dalam kegiatan MGMP. Forum MGMP membahas silabus dan RPP kurikulum 2013. Forum MGMP bekerja sama dengan perguruan tinggi. Guru berusaha untuk meningkatkan mutu pembelajaran di sekolah. Guru menggunakan alat dan media yang mutakhir.
Guru selalu mengumpulkan data hasil belajar peserta didik dan ditinjau secara periodik. Guru mengembalikan hasil belajar kepada peserta didik dan meninjau kemajuan hasil belajar tersebut. Sekolah selalu melaporkan hasil belajar peserta didik kepada orang tua dan wali.Pada kuesioner yang di isi oleh guru PJOK, pada jawaban selalu mendapatkan skor 12 dari 28 total skor yang ada, dan mendapatkan persentase sejumlah $42,8 \%$. Jawaban sering mendapat skor 0 dan mendapatkan persentase sejumlah $0 \%$, pada jawaban jarang mendapat mendapat persentase $7,1 \%$ dan persentase 10,7\% untuk jawaban tidak pernah.

\section{Tabel 9. Analisis SWOT Standar Pengelolaan}

\begin{tabular}{ll}
\hline Strenght & - Guru mengembangkan kurikulum 2013 sesuai potensi dan karakter masyarakat. \\
& - Guru aktif dalam MGMP dan selalu membuat silabus. \\
& - Guru selalu mengumpulkan data hasil belajar peserta didik. \\
& Pihak sekolah selalu melaporkan hasil belajar peserta didik kepada orang tua wali. \\
\hline
\end{tabular}


Suhardiyantoro A W, Evaluasi Pelaksanaan Kurikulum 2013 pada Matapelajaran Pendidikan Jasmani Olahraga

\begin{tabular}{lll}
\hline Weakness & $\bullet$ & Data hasil kemajuan belajar sering ditinjau secara berkala. \\
& $\bullet$ & Guru tidak memberikan remidi secara berkala. \\
\hline Opportunity & $\bullet$ & Forum guru MGMP harus mengupayakan kerja sama dengan LPMP maupun PT. \\
& $\bullet$ & Guru harus berupaya menggunakan metode, alat maupun media yang mutakhir. \\
\hline Threatening & $\bullet$ & Daya saing dari kota-kota lain.
\end{tabular}

diketahui bahwa standar pengelolaan ini sudah baik dan perlu adanya penguatan yaitu bekerja sama dengan pihak-pihak lain seperti Perguruan Tinggi yang ada dikota tersebut.

\section{PEMBAHASAN}

Evaluasi sangat erat hubungannya dengan sebuah program atau lembaga penyelenggara pendidikan. Keberadaan evaluasi program secara konsep terintegrasi dengan evaluasi pendidikan. Menurut Sukardi (2014:7) menyatakan bahwa " keberadaan evaluasi program juga penting ketika seorang penyelenggara lembaga kependidikan dan kepelatihan mengambil kebijakan untuk menilai program atau proyek dilaksanakan dengan efektif dan efisien".

Menurut Tayibnapis (1989:6) "bila anda mengevaluasi suatu program, anda secara teratur mengumpulkan informasi tentang bagaimana proram itu berjalan, tentang dampak yang mungkin terjadi atau untuk menjawab pertanyaan yang diminati. Kadang-kadang informasi yang dikumpulkan digunakan untuk membuat keputusan tentang proram itu".

Kurikulum 2013 merupakan salah satu program pemerintah di bidang pendidikan yang harus diikuti oleh semua komponen satuan pendidikan yang ada di Indonesia. Oleh karena itu, untuk mengukur dan menilai sampai sejauh mana implementasi satuan pendidikan di Indonesia ini dilakukan kegiatan evaluasi program pendidikan. Ruang lingkup evaluasi pendidikan pada penelitian ini adalah evaluasi pelaksanaan kurikulum 2013 pada matapelajaran pendidikan jasmani olahraga dan kesehatan di SMPN 6 Malang.

Berikut ini dijabarkan pembahasan hasil penelitian dengan strategi pengembangannya berdasarkan hasil penelitian pada 8 standar kurikulum 2013.

\section{Standar Isi}

Permendikbud no 64 tahun 2013 meliputi: a) Karakteristik materi, b) Kesesuaian materi, c) Kecukupan materi, d) Keluasan materi, e) Kedalaman materi.

Berdasarkan hasil penelitian menggunakan analisis SWOT, maka strategi untuk meningkatkan dan mengembangkan standar isi adalah dengan membuat pembelajaran PJOK lebih menyenangkan dan sederhana. Karena pada dasarnya peserta didik SMP sangat suka bermain dan hal-hal yang membuat mereka senang. Salah satu cara untuk memasukkan materi yang diharapkan guru adalah pembelajaran yang menyenangkan dan mudah untuk dipahami oleh peserta didik. Untuk mengatasi peserta didik yang tidak masuk, guru bisa menyuruh dia untuk sharing dengan teman yang masuk dan setelah itu memberi materi yang dia lewatkan.

\section{Standar Penilaian}

Indikator standar penilaian menurut Permendikbud no 66 tahun 2013 meliputi: a) Penilaian Otentik, b) Penilaian diri, c) Penilaian berbasis portofolio, d) Ulangan harian, e) Ulangan tengah semester, f) Ulangan akhir semester, g) Penilaian kompetensi sikap, h) Penilaian kompetensi pengetahuan, i) Penilaian kompetensi keterampilan.

Berdasarkan pada hasil penelitian menggunakan analisis SWOT, maka strategi untuk meningkatkan dan mengembangkan standar penilaian adalah dengan mengadakan tes lisan dan memberi tugas portofolio. Tes lisan diberikan agar peserta didik dapat belajar berbicara di depan umum, banyak anak yang cenderung diam dan pasif karena mereka takut untuk mengeluarkan pendapat atau jawaban mereka. Untuk tugas portofolio dapat diberikan guru sebagai tugas penguatan kepada peserta didik. Selain kedua hal di atas, guru juga harus menghimbau pada peserta didik untuk tidak menyalahgunakan penilaian diri dan penilaian teman sejawat. Kedua penilaian tersebut diberikan dengan tujuan peserta didik mampu untuk menilai dan 
mengevaluasi diri sendiri dan melatih peserta didik agar lebih perhatian kepada temannya.

\section{Standar Kompetensi Lulusan}

Indikator standar kompetensi lulusan menurut Permendikbud no 54 tahun 2013 meliputi: a) Sikap, b) Pengetahuan, c) Keterampilan.

Berdasarkan hasil penelitian menggunakan analisis SWOT, maka strategi untuk meningkatkan dan mengembangkan standar kompetensi lulusan adalah dengan memberikan pembelajaran bukan hanya dari segi materi, melainkan pembelajaran moral dan etika. Jika mereka lulus nanti maka diharapkan merak mempunyai akhlak dan etika yang baik. Selain moral dan etika mereka juga harus berkualitas dalam hal pengetahuan umum dan khusus sesuai tingkatan pendidikan mereka.

Rintangan yang dihadapi oleh guru dan peserta didik adalah lingkungan tempat peserta didik bergaul dan lingkungan rumahnya. Hal ini akan sangat berpengaruh pada peserta didik, karena waktu yang merka habikan di lingkungan tersebut lebih banyak daripada di lingkungan sekolah. Oleh karena itu peran guru dalam memberi wawasan peserta didik harus lebih menekankan pada moral dan etika, tetapi tidak mengesampingkan materi yang ada.

\section{Standar Pendidik dan Tenaga kependi- dikan}

Indikator standar pendidik dan tenaga kependidikan menurut Permendiknas no 32 tahun 2008 dan menurut Mulyasa (2007) meliputi: a) Kompetensi pedagogik, b) Kompetensi kepribadian, c) Kompetensi profesional, d) Kompetensi sosial.

Berdasarkan hasil penelitian menggunakan analisis SWOT, maka strategi untuk meningkatkan dan mengembangkan standar pendidik dan tenaga kependidikan adalah meningkatkan kemampuan manajemen waktu guru. Apabila seorang guru memiliki jabatan lain di sekolah, sebagai contoh menjadi wakil kepala sekolah urusan tertentu atau bagian-bagian tertentu di sekolah. Hal ini dapat menyebabkan menurunnya tingkat fokus guru, karena guru tidak hanya memikirkan pembelajarannya melainkan jabatan lain yang dia kerjakan. Untuk menjadi guru yang berkualitas, seorang guru harus meningkatkan kemampuan sesuai 4 kompetensi guru.

\section{Standar Sarana-Prasarana}

Indikator standar sarana prasarana menurut Permendiknas no 24 tahun 2007 meliputi: a) Bebas bahaya, b) Bebas ancaman kesehatan, c) Memiliki akses keselamatan, d) Bebas pencemaran air, e) Bebas kebisingan, f) Bebas pencemaran udara, g) Sistem sirkulasi udara, h) Sistem penerangan, i) Ruang kelas, j) Ruang olahraga, k) Alat-alat olahraga.

Menurut Yusuf (2012) meliputi : Sarana olahraga meliputi bola basket, bola voli, bola sepak, jaring, gawang, ring basket, net voli, patcing pad, body protector, raket, bendera, palang, lembing, balok start, tongkat estafet, matras, peti lompat, tali lompat, tiang, mistar untuk lompat tinggi.

Prasarana olahraga meliputi lapangan atletik, lapangan sepak bola, lapangan basket, lapangan voli, lapangan kasti ruang senam dan lapangan serba guna.

Berdasarkan hasil penelitian menggunakan analisis SWOT, maka strategi untuk meningkatkan dan mengembangkan standar sarana-prasarana adalah dengan menambah alat untuk menangani bencana, sebagai contoh adalah menambah alat pemadam kebakaran di sekolah. Memasang alat pereda kebisingan pada ruangan yang dekat dengan jalan raya, karena hal itu bisa mengganggu situasi pembelajaran. Selain menambah alat-alat, meningkatkan kebersihan lingkungan merupakan hal yang harus dilakukan pihak sekolah.

Kebersihan kamar mandi dan sekitar ruang belajar harus menjadi fokus utama, hal ini dapat dilakukan dengan cara menambah tempat sampah yang ada di bagian rawan sampah. Selain itu sekolah juga harus membuat tempat parkir, atau memperlebarnya. Karena jika tempat berolahraga digunakan sebagai tempat parkir, maka hal itu bisa mengganggu pembelajaran dan dapat merusak kendaraan yang parkir di sekitar tempat berolahraga.

\section{Standar Pembiayaan}

Indikator standar pembiayaan menurut Permendiknas no 69 tahun 2009 meliputi: a) Pengadaan alat-alat olahraga, b) Biaya 
Suhardiyantoro A W, Evaluasi Pelaksanaan Kurikulum 2013 pada Matapelajaran Pendidikan Jasmani Olahraga dan Kesehatan di SMPN 6 Malang Dengan Menggunakan Analisis SWOT

asuransi, c) Biaya pemeliharaan saranaprasarana.

Berdasarkan hasil penelitian menggunakan analisis SWOT, maka strategi untuk meningkatkan dan mengembangkan standar pembiayaan adalah dengan mengadakan dana asuransi kepada guru dan peserta didik. Mempercepat kegiatan perbaikan sarana atau prasarana di sekolah. Untuk perbaikan sarana-prasarana dananya memang ada, tetapi terkadang untuk penyelesaiannya itu tergolong lambat. Semakin lama proses perbaikan tersebut maka semakin lama juga hal itu mengganggu pembelajaran.

\section{Standar Pengelolaan}

Indikator standar pengelolaan menurut Pemendiknas no 19 tahun 2007 meliputi: a) Pengembangan kurikulum sesuai daerah, b) MGMP, c) Mutu pembelajaran, d) Peninjauan program penilaian.

Berdasarkan hasil penelitian menggunakan analisis SWOT, maka strategi untuk meningkatkan dan mengembangkan standar pengelolaan adalah dengan meningkatkan hubungan dengan guru-guru lain pada forum MGMP. MGMP sendiri juga harus meningkatkan kerja sama dengan perguruan tinggi yang ada di kota tersebut, karena hal itu bisa menguntungkan kedua pihak. Kedua hal di atas harus dilakukan karena agar meningkatkan mutu pendidikan yang ada di kota tersebut, karena kota-kota lain sedang melakukan hal yang sama. Selain itu meninjau secara teratur hasil belajar peserta didik dan melaporkannya kepada orang tua wali murid.

\section{KESIMPULAN}

Pada variabel Standar Isi, pelaksanaan dan implementasi kurikulum 2013 sudah berjalan sangat baik. Hal yang perlu dipertahankan adalah peserta didik diberikan tugas pengayaan, guru menggunakan penilaian otentik dan penye-derhanaan materi oleh guru. Hal yang perlu diperbaiki adalah guru tidak bisa meng-gunakan metode dan model pembelajaran yang sama untuk peserta didik yang ber-beda.

Pada variabel Standar Penilaian, pelaksanaan dan implementasi kurikulum 2013 sudah berjalan sangat baik. Hal yang perlu dipertahankan adalah guru menggunakan penilaian diri dan teman sejawat, guru mengadakan ulangan harian, ulangan tengah semester, ulangan akhir semester, guru menga-dakan remidi untuk peserta didik yang belum mencapai kriteria kelulusan, guru menggunakan observasi untuk menilai peserta didik. Hal yang perlu diperbaiki adalah mengadakan tes lisan dan tugas portofolio kepada peserta didik.

Pada variabel Standar Proses, pelaksanaan dan implementasi kurikulum 2013 sudah berjalan sangat baik. Hal yang perlu dipertahankan adalah guru membuat program tahunan dan semester, RPP guru sesuai kurikulum 2013, guru memasukkan pembelajaran konseptual. Hal yang perlu diperbaiki adalah tidak sesuainya model dan metode untuk peserta didik.

Pada variabel Standar Kompetensi Lulusan, pelaksanaan dan implementasi kurikulum 2013 sudah berjalan baik. Hal yang perlu dipertahankan adalah guru membentuk peserta didik untuk beriman, berilmu, percaya diri, bertanggung jawab, memiliki pengetahuan faktual, pengetahuan konseptual dan prosedural. Hal yang perlu dibenahi adalah membentuk peserta didik memerlukan waktu yang lama dan konsisten.

Pada variabel Standar Pendidik dan Tenaga Kependidikan, pelaksanaan dan implementasi kurikulum 2013 sudah berjalan sangat baik. Hal yang perlu dipertahankan adalah guru dapat berkomunikasi dengan efektif dan efisien, menilai secara objektif, dapat bijaksana dan adil, dinamis dan mudah bergaul. Hal yang perlu diperbaiki adalah guru dapat mengevaluasi kinerjanya dan manajemen waktu guru.

Pada variabel Standar SaranaPrasarana, pelaksanaan dan implementasi kurikulum 2013 sudah berjalan sangat baik. Hal yang perlu dipertahankan lingkungan bebas bahaya dan rimbun oleh pohon, bangunan kokoh, terhindar dari pencemaran air dan udara, meja dan kursi mencukupi, tempat olahraga tidak mengganggu pembelajaran yang lain. Hal yang perlu diperbaiki adalah menyediakan lahan parkir sehingga tidak mengganggu pembelajaran pendidikan jasmani.

Pada variabel Standar Pembiayaan, pelaksanaan dan implementasi kurikulum 2013 sudah berjalan cukup baik dan cukup untuk biaya operasional sekolah. Hal yang 
perlu dipertahankan adalah sekolah menyediakan dana untuk perbaikan sarana-prasarana olahraga, biaya kecelakaan di sekolah di tanggung oleh pihak sekolah. Hal yang perlu diperbaiki adalah tidak ada biaya asuransi untuk peserta didik dan guru.

Pada variabel Standar Pengelolaan, pelaksanaan dan implementasi kurikulum 2013 sudah berjalan sangat baik. Hal yang perlu dipertahankan guru aktif dalam MGMP, guru selalu mengumpulkan data hasil belajar peserta didik dan pihak sekolah selalu melaporkannya kepada orang tua wali peserta didik. Hal yang perlu diperbaiki adalah kerjasama dengan pihak lain khususnya perguruan tinggi di sekitar sekolah.

\section{SARAN}

Pada Standar Isi ini masih perlu perbaikan berdasarkan hasil evaluasi, yaitu meningkatkan dan mengembangkan pembelajaran agar lebih sederhana dan menyenangkan.

Pada Standar Penilaian ini masih perlu perbaikan berdasarkan hasil evaluasi, yaitu mengadakan tes lisan dan tugas portofolio, dan menghimbau peserta didik agar tidak menyalahgunakan penilaian diri dan penilaian teman sejawat.

Pada Standar Proses masih perlu perbaikan berdasarkan hasil evaluasi, yaitu meningkatkan dan mengembangkan RPP kurikulum 2013. Pengaturan jadwal mata pelajaran PJOK, karena tidak efektif proses pembelajarannya jika menggunakan 1 lapangan untuk 2 kelas.

Pada Standar Kompetensi Lulusan masih perlu perbaikan berdasarkan hasil evaluasi, yaitu penambahan materi moral dan etika.

Pada variabel Standar Pendidik dan Tenaga Kependidikan masih perlu perbaikan berdasarkan hasil evaluasi, yaitu meningkatkan manajemen waktu pendidik dan mengembangkan 4 kompetensi guru. Menambah tenaga guru berkualitas agar pembelajaran tidak terganggu dengan jumlah guru yang kurang.

Pada variabel Standar Sarana-Prasarana masih perlu perbaikan berdasarkan hasil evaluasi, yaitu menambah alat-alat keamanan dan menambah alat-alat olahraga yang belum ada di sekolah. Kebersihan lingkungan dan penambahan lahan parkir di sekolah juga perlu diadakan.

Pada Standar Pembiayaan masih perlu perbaikan berdasarkan hasil evaluasi, yaitu mengadakan biaya asuransi kepada guru dan peserta didik, selain itu mempercepat proses perbaikan sarana

Pada Standar Pengelolaan masih perlu beberapa perbaikan berdasarkan hasil evaluasi, yaitu meningkatkan kerja sama di MGMP dan perguruan tinggi.

\section{DAFTAR RUJUKAN}

Budi, B,S. 2014. Skripsi-Strategi Guru dalam menghadapi Kurikulum 2013 di SMA Negeri 2 Surakarta. Surakarta: Universitas Sebelas Maret.

Budiwanto, S. \& Mu'arifin. 2006 Evaluasi Pembelajaran Pendidikan Jasmani. Malang: Fakultas IImu Pendidikan Universitas Negeri Malang.

Bungin, M. B. 2011. Metodologi Penelitian Kuantitatif. Jakarta: Kencana Prenada Media Group.

Dwiyogo, W, D. 2010. Dimensi Teknologi Pembelajaran Pendidikan Jasmani \& Olahraga. Malang: Wineka Media.

Husdarta, J, S. 2011. Manajemen Pendidikan Jasmani. Bandung: Alfabeta.

Jawa Pos National Network. 2014. Permendikbud 160/2014: KTSP sampai 2019/2020, (Online), (http:// www.jpnn.com), diakses 28 Januari 2015.

Kurniady, D,A. 2011. Pengelolaan Pembiayaan Sekolah Dasar di Kabupaten Bandung. (online). Diakses pada 28 Desember 2015.

Moleong, L, J. 2010. Metodologi Penelitian Kualitataif edisi revisi. Bandung: PT Remaja Rosdakarya. 
Suhardiyantoro A W, Evaluasi Pelaksanaan Kurikulum 2013 pada Matapelajaran Pendidikan Jasmani Olahraga dan Kesehatan di SMPN 6 Malang Dengan Menggunakan Analisis SWOT

Mulyasa, E. 2007. Standar Kompetensi dan Sertifikasi Guru. Bandung: PT Remaja Rosdakarya.

Nasution, S. 2009. Asas-Asas Kurikulum. Jakarta: PT Bumi Aksara.

Nasution, S. 2010. Kurikulum dan Pengajaran. Jakarta: PT Bumi Aksara.

Permendikbud nomor 81A tahun 2013 tentang Implementasi Kurikulum Pedoman Evaluasi Kurikulum. (Online), (htpp://www.kemendikbud.go.id), diakses 28 Januari 2015.

Permendikbud nomor 64 tahun 2013 tentang Standar isi. (Online), (htpp://www.kemendikbud.go.id), diakses 28 Januari 2015.

Permendikbud nomor 65 tahun 2013 tentang Standar Proses. (Online), (htpp: //www.kemendikbud.go.id), diakses 28 Januari 2015.

Permendikbud nomor 54 tahun 2013 tentang Standar Kompetensi Lulusan. (Online), (htpp://www.kemendikbud. go.id), diakses 28 Januari 2015.

Permendikbud nomor 66 tahun 2013 tentang Standar Penilaian. (Online), (htpp:// www.kemendikbud.go.id), diakses 28 Januari 2015.

Permendiknas nomor 24 tahun 2007tentang standar sarana dan prasarana sekolah pendidikan umum. (online). (htpp://www.kemendikbud.go.id), diakses 28 Januari 2015.

Permendiknas nomor 69 tahun 2009 tentang standar biaya operasional. (online). (htpp://www.kemendikbud.go.id), diakses 28 Januari 2015.

Permendiknas nomor 32 tahun 2008 tentang standar pendidik. (online). (htpp: //www.kemendikbud.go.id), diakses 28 Januari 2015.
Permendiknas nomor 19 tahun 2007 tentang standar pengelolaan. (online). (htpp: //www.kemendikbud.go.id), diakses 28 Januari 2015

Rangkuti, F. 2003. Analisis SWOT Teknik Membedah Kasus Bisnis. Jakarta: PT Gramedia Pustaka Utama.

Sawitri, P. 2014. Manajemen Strategi. Jurnal Manajemen, (Online), diakses 28 Januari 2015.

Suara Pembaruan. 2014. Mendikbud Evaluasi Kurikulum 2013, (Online), (htpp://www.beritasatu.com), diakses 28 Januari 2015.

Sudjana, N. 1990. Penilaian Hasil Proses Belajar Mengajar. Bandung: PT Remaja Rosdakarya.

Sugiyono. 2011. Metode Penelitian Kuantitatif, Kualitatif dan $R \& D$. Bandung: Alphabeta.

Sukardi. 2014. Evaluasi Program Pendidikan dan Kepelatihan. Jakarta: PT Bumi Aksara.

Sukmadinata, N,S. 2013. Pengembangan Kurikulum Teori dan Praktek. Bandung: PT Remaja Rosdakarya.

Sunarti, \& Rahmawati, S. 2014. Penilaian dalam Kurikulum 2013. Yogyakarta: ANDI.

Tayibnapis, F, Y. 1989. Evaluasi Program. Jakarta. Departemen Pendidikan dan Kebudayaan.

Umar, H. 2008. Desain Penelitian MSDM dan Perilaku Karyawan. Jakarta: Rajagrafindo Persada.

Universitas Negeri Malang. 2010. Pedoman Penulisan Karya IImiah Edisi Kelima. Malang: UM PRESS.

Yusuf, M. 2012. Study Sarana dan Prasarana Pendidikan Jasmani Sekolah Dasar Se-Kecamatan Slogohimo Kabupaten Wonogiri dalam Pelaksanaan Kurikulum Tingkat 
102 GELANGGANG PENDIDIKAN JASMANI INDONESIA, Volume 1, Nomor 1, Tahun 2017, Halaman 87-102

Satuan Pendidikan Tahun 2012. (online). Diakses pada 28 Desember 2015. 